\title{
A Proposed PABITRA Study Area on Lauru Island, Western Solomon Islands ${ }^{1}$
}

\author{
W. C. McClatchey, ${ }^{2,3}$ M. Q. Sirikolo, ${ }^{4}$ H. Boe, ${ }^{5}$ E. Biliki, ${ }^{5}$ and F. Votboc ${ }^{5}$
}

\begin{abstract}
The island of Lauru (Choiseul) in the western Solomon Islands is a high (up to 1,060 m) mixed volcanic and limestone uplifted island, located between $6.5^{\circ}$ and $7.5^{\circ} \mathrm{S}$ latitude and $156.5^{\circ}$ and $157.5^{\circ} \mathrm{E}$ longitude. The central part of the island is suggested for inclusion in the Pacific-Asia Biodiversity Transect (PABITRA) system. The proposed area consists of the north-central coast, Mount Barokasa $(850 \mathrm{~m})$, Mount Maetabe $(1,060 \mathrm{~m})$, and the primary watershed systems that drain these mountains and the central plateau between them. Some of the concerns and expectations of traditional land owners and the Solomon Islands government are considered. These play important roles in any research activity and will be central to the success or failure of the project. The Solomon Islands, Lauru, and the specific study area are briefly described with synopses of previous research and current, preliminary research activities. Preliminary species checklists are given for plants and vertebrates in the area. Initially we propose to establish two transects, each passing through two biomes suitable for comparisons with similar biomes in other PABITRA sites: the tropical montane cloud forest of Mount Maetabe (the highest point in the island), and the lowland rain forests, between 200 and $500 \mathrm{~m}$ in elevation to the southwest of Susuka at the base of Mount Barokasa. The two proposed transects will stretch through two different watersheds, one of which has had traditional agriculture practiced in the coastal strand area and the other of which has had traditional agriculture practiced in the lowland forest of midelevations. A research agenda is proposed that will help achieve key objectives of developing local research capacity and internal biodiversity management systems while conserving traditional knowledge.
\end{abstract}

Following THE 1994 DIVERSITAS forum in Paris, DIWPA (DIVERSITAS in Western Pacific and Asia) was formed to implement the DIVERSITAS agenda for biodiversity research in Asia and the western Pacific. In

\footnotetext{
${ }^{1}$ Manuscript accepted 16 April 2004.

${ }^{2}$ Corresponding author.

${ }^{3}$ Department of Botany, University of Hawai'i at Mānoa, Honolulu, Hawai'i 96822.

${ }^{4}$ Department of Forestry, Environment and Conservation Division, Ministry of Natural Resources, P.O. Box G24, Honiara, Solomon Islands.

${ }^{5}$ Ririo Cucuen Cultural Project, Susuka, Lauru, Solomon Islands.
}

Pacific Science (2005), vol. 59, no. 2:213-239

(C) 2005 by University of Hawaici Press

All rights reserved
1998, PABITRA (Pacific-Asia Biodiversity Transect) was formed to organize research activities in the tropical Pacific islands in association with DIWPA (Mueller-Dombois 1998). The horizontal (trans-Pacific) transect for proposed biodiversity study passes through the Solomon Islands (see Figure 2 in introductory paper in this issue [MuellerDombois and Daehler 2005]). PABITRA research in each site along the horizontal transect as well as in the proposed site on Lauru Island is intended to: (1) produce an inventory of biological diversity, (2) conduct an analysis of the ecosystems present, (3) integrate an inventory with ecosystem studies through vertical transects traversing a range of ecosystems, and (4) conduct comparative studies of ecosystems with other islands along the horizontal trans-Pacific transect to test hypotheses of biodiversity relationships and 
of distributional vicariance colonization of the Pacific islands.

\section{A Partnership Agreement}

In 1998 researchers of the Solomon Islands National Herbarium and their Solomon Island and foreign research partners agreed to form a collaborative biodiversity research group: Solomon Islands Biodiversity Initiative (SIBI). SIBI is intended to organize and execute biodiversity research projects that meet the agenda of PABITRA and serve to document the diverse ethnobotanical knowledge of the Solomon Islands. The SIBI agenda overlaps substantially with the objectives of PABITRA and includes special emphasis upon: recognition and respect for local authorities; training/capacity building of Solomon Islanders; developing databases of ethnobotanical knowledge; transference of newly developed knowledge to Solomon Islanders; and patent protection, licensing, and copyright protection of Solomon Islands knowledge and customary information specifically for the benefit of the originators of the knowledge (Solomon Islanders). Since its formation, SIBI researchers have been conducting preliminary site visits in efforts to identify areas where biodiversity research may be most effectively conducted. Because of the ethnobotanical and capacity-building emphases of SIBI, potential study areas with notable participatory interest from local populations are being considered for the first studies. Following initial visits and discussions with landowners, the Ririo tribe on the north-central coast of Lauru (Choiseul) island expressed substantial interest in participating in SIBI projects.

Before initiation of preliminary SIBI research activities, four major areas of concern were identified that needed to be addressed in the organization of all research activities: (1) cultural, (2) political, and (3) management concerns with biodiversity research activities, and (4) integration of local peoples into biodiversity research projects. These areas span the range of human interactions with the environment and with one another. The primary aspects of each are summarized here.

\section{Cultural Concerns with Biodiversity Research Activities}

Holders of customary (traditional) ethnobotanical knowledge (TEK) in the Solomon Islands may be concerned about sharing their information with other people. In some cases cultural protocols do not allow sharing knowledge with members of other cultures or even with other members of their own culture. In other cases cultural protocols do allow transference of knowledge, but knowledge holders are not convinced that members of other cultures will be responsible with the information provided. Finally, some individuals and cultural groups are concerned about the economic potential of their knowledge and wish to receive a reasonable financial reward or royalty for sharing their information.

These same concerns are sometimes expressed by cultural leaders and advocates about collection and identification of biological diversity from customary lands. Because traditional land tenure is not fully resolved in many parts of the Solomon Islands and there is occasionally some tension between traditional leaders and the federal government, ownership of biological resources remains tenuous.

\section{Political Concerns with Biodiversity Research Activities}

The Solomon Islands is signatory to the Convention on Biological Diversity and other international treaties that grant sovereignty of biological resources specifically to the federal government. Participating Solomon Islands government agencies, though, recognize the role of customary land and resource owners in the sites visited by SIBI in 1998. Despite this recognition, a history of logging, mining, and fishing claims has left many customary landowners suspicious of government workers. An important part of the proposed research activities will be a balance of recognition of national sovereignty and local customary ownership of biodiversity and knowledge. 


\section{Management Concerns with Biodiversity Research Activities}

Because the Solomon Islands federal government has very limited resources with which to work, SIBI will be training to encourage conservation activities by local resource owners and users. It is recognized that customary resource management and use practices may be either conservative or destructive, but for the purpose of the proposed research, an assumption will be made that traditional practices are conservative unless or until otherwise determined. SIBI will therefore encourage the continuation of customary practices and moderation in adoption of modern practices that have not previously been shown to be equally conservative. Specific areas of management include usage of forests (timber and nontimber), agricultural areas, and marine resources.

\section{Integration of Local Peoples into Biodiversity Research Projects}

Biodiversity transect studies can and should be conducted in culturally sensitive ways that include the permission, perspectives, and participation of local peoples. Investing the time to secure access from landholders can encourage local understanding of research, acceptance of research results, and interest in participation in research projects. Respect for physical and intellectual property rights is a responsibility of all scientists. Inclusion of local cultures in research can serve to reinforce positive cultural conservation perspectives resulting in longer-term stability of the study site environments. Cultural participants who are trained in research techniques, rationale, and data interpretation learn valuable skills that can be applied in long-term studies. They may also acquire or renew their appreciation and knowledge of their own traditional cultural lands. In this regard, the Ririo Cucuen Cultural Project is expected to play an important role in PABITRA activities on Lauru. The project involves a group of elders and advisors from the Ririo language community whose purpose is to document and preserve traditional knowledge and language about their culture.

\section{SITE DESCRIPTION AND PRELIMINARY RESULTS}

The first suggested site of study is the river drainage/valley owned by the people of the Ririo tribe on the north-central coast of Lauru. The principal village in this area is Susuka, which is made up of Ririo and Babatana language speakers. For each of the following topics, general statements are first made about the island of Lauru followed by more specific statements for the study site of Susuka.

\section{Geography}

The Solomon Islands consists of more than 1,000 small and large islands from about $155^{\circ}$ to $170^{\circ} \mathrm{E}$ longitude and $5^{\circ}$ to $12^{\circ} \mathrm{S}$ latitude (see Figure $1 A$ ). The islands were formed on the Pacific Plate near the Ontong Java Plateau about 40 million yr ago (Yan and Kroenke 1993). Plate tectonic volcanic activity formed an extensive arc of high islands that have since eroded into what is now known as Bougainville, Solomon Islands, and Vanuatu (Coleman 1970, Hackman 1973.) Because of these origins the islands are largely composed of basalt or in some cases sand and basalt or uplifted and dissected limestone shelves (Hansell and Wall 1976a.) The major islands (including Lauru, discussed here) also have evidence of more recent volcanic activities that have resulted in additional andesites and basalts.

Lauru, also known as Choiseul, is located between $6.5^{\circ}-7.5^{\circ} \mathrm{S}$ latitude and $156.5^{\circ}-$ $157.5^{\circ} \mathrm{E}$ longitude at the northwestern corner of the political Solomon Islands. Geographically, the Solomon Islands also includes the island of Bougainville that is northwest of Lauru, but due to colonial political partitioning, Bougainville is currently part of Papua New Guinea. The island is long $(185+\mathrm{km})$ and narrow (averaging about $30 \mathrm{~km}$ in width), extending from the northwest to the southeast. The total land area of Lauru is approximately $3,086 \mathrm{~km}^{2}$. Lauru is mountainous with many rivers, the largest of which is the Kolobaqara. The Kolobaqara is located on the south-central part of Lauru, where it drains 


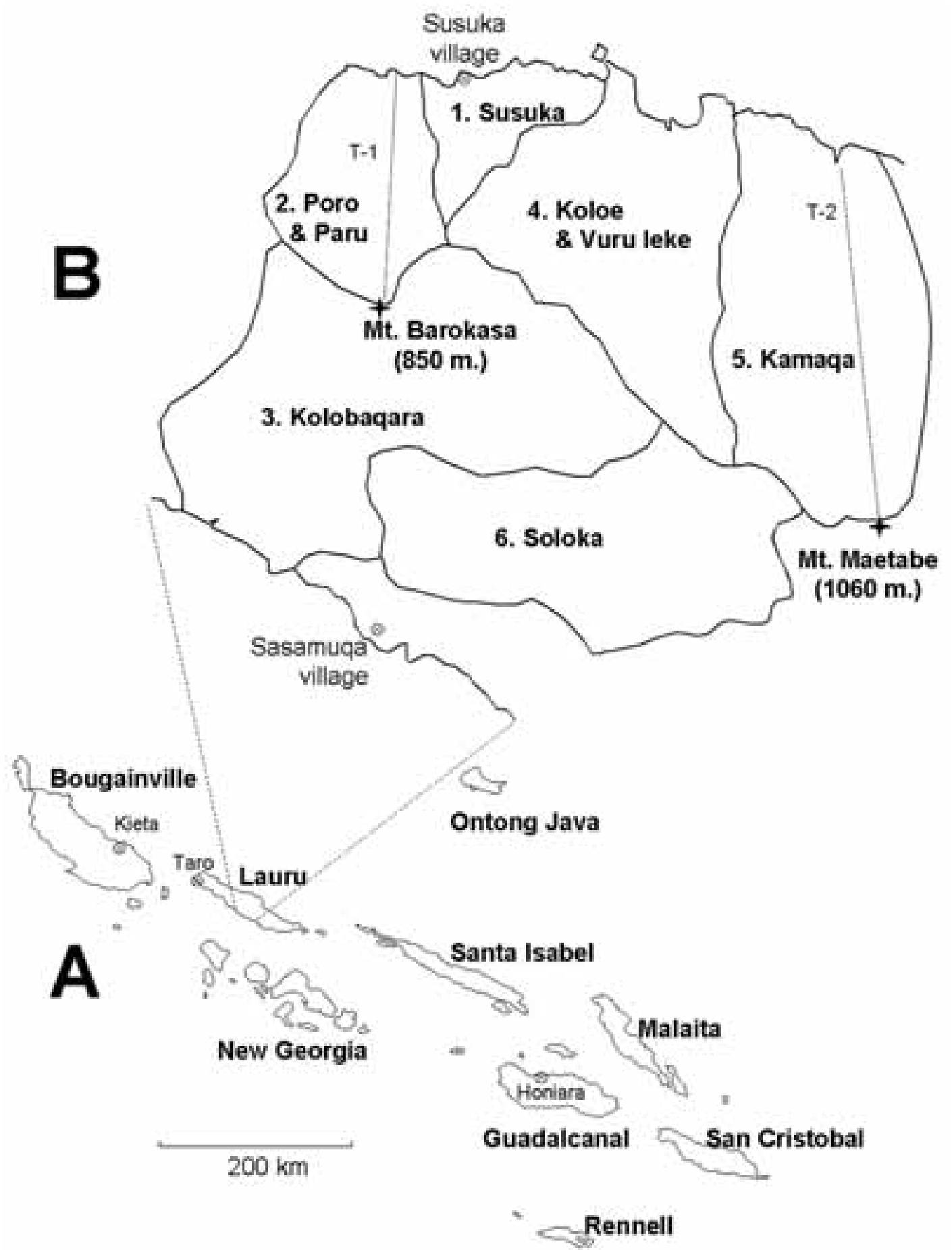

FIgURE 1. $A$, The geographical Solomon Islands including Bougainville and Rennell Islands. $B$, Central Lauru proposed site with six watershed units and two transects (T-1, T-2). 
the central plateau (approximately $480 \mathrm{~km}^{2}$ ) and western slopes of Mount Maetabe. Mount Maetabe is a volcanic cone reaching just to the east of the center of the island and is the highest point $(1,060 \mathrm{~m})$ on Lauru (Hansell and Wall 1976b).

The proposed study area includes six major watershed units (Figure $1 B$ ) spanning the center of Lauru Island and including the two highest peaks. The area is located at $7.1^{\circ} \mathrm{S}$ latitude and $157.2^{\circ} \mathrm{E}$ longitude, bounded on the north-northeast by the South Pacific Ocean, the east-southeast by slopes of Mount Maetabe, the south-southwest by New Georgia Sound, and the west-northwest by the upper reaches of the Poro and Kolobaqara River drainage systems. The areas have been numbered (1-6) in the order of the proposed research based upon local permission to work in each area. Landowners in areas 1-2 have already granted permission to conduct the proposed research in their lands. Areas 3-6 are watersheds for which partial or no permission has yet been obtained. The first area to be studied comprises the watershed system of Susuka Village on the north-central coast of Lauru. This area is currently the most heavily modified area of the proposed site. Much of the watershed is made up of anthropogenic vegetation zones. The second area to be studied is composed of the watersheds of the Poro and Paru Rivers. This watershed is the principal north-slope drainage of Mount Barokasa. The lower levels of the watershed contain scattered human settlements and gardens, but the upper areas are relatively untouched by modern activities. The proposed first transect would be placed in this watershed running roughly from north to south from the Pacific Ocean to the top of Mount Borokasa (Figure 1B, T-1). The third area comprises the northern watershed system of the Kolobaqara river that drains the southern and eastern sides of Mount Barokasa as well as much of the central plateau that lies between Mount Barokasa and Mount Maetabe. For our purposes we are interested in a mixture of lower- and higher-altitude portions of this watershed reflecting a mixture of anthropogenic modification regimes. The fourth area is the watershed of the Koloe and Vuru leke Rivers. This area contains only moderate altitudinal and vegetational gradients, with the rivers draining the lower areas of the north-central plateau. Many parts of this system contain swamps and bogs. The fifth area is the Kamaqa River watershed. This area features the greatest altitudinal and vegetational gradients in the proposed site. The upper areas of this system reach the top of Mount Maetabe and include elements of montane forest and bogs. The second transect is proposed for this area running roughly north to south parallel to the first transect (Figure $1 B$, $\mathrm{T}-2$ ). The sixth area is made up of the watershed of the Soloka River, which is the largest tributary of the Kolobaqara River. This area may or may not be studied depending upon the results from the first five areas. This area offers contrasting south-facing slopes in a rugged central plateau area that differ substantially from area 4 that drains the northfacing slopes of the same plateau.

\section{Geology}

Lauru is a relatively young island formed from rapid uplift in the Lower Tertiary and volcanic activity beginning in the Miocene and extending until the Holocene (Coleman et al. 1965a,b). Uplift has resulted in several substrates, the most important of which is limestone from former seabeds and block faults that has formed low hills and some of the lower mountains in the center of the island. Uplifted sandstone and mudstone shelves occurring on the west side of Mount Maetabe are termed "Kamanga Grit" (Coleman et al. 1965a,b). These shelves are intermixed with basalt blocks in the plain and drainage of the Kolobaqara River (PudseyDawson 1965). Volcanic activity has created andesitic/basaltic mountains such as Mount Maetabe, which have been termed "Matambe Volcanics" (Coleman et al. 1965a,b). Grover (1958) conducted two geological transect studies on Lauru, the first in the northwestern one-third of the island between Vosa on the south coast and Ogo on the north coast. The second transect through the middle section of the island began at Paqoe on the north coast, traversed the southeastern 
slope of Mount Maetabe, and ended on the southern shore at Lutee. These transects revealed that much of the island has sections of relatively recent andesite lava flows from Mount Maetabe overlaying the older uplifted materials. This has produced a folded and intercalated landscape (Birch 1989).

\section{Soils}

A wide range of soils is present on Lauru. These are summarized by Hansell and Wall (1976b). Low-altitude river drainages often have mollisols, with the surrounding lower slopes having oxisols. Higher upland slopes are more likely to consist of dystropepts or haplorthoxs.

Study areas 1, 2, and 3 consist of the southern half of the Ririo geological district (Hughes 1979, 1981). This area is bounded on the southeast by the uplifted slopes that form the outer margin of the Kolobaqara River drainage and on the southwest by the ridges of Mount Maetabe. Much of this area consists of basalt Vosa Lavas and amphibolite Choiseul Schists. The coastline is rimmed by narrow fringing reefs with intermittent breaks indicating recent sea level changes. Intermittent mangrove swamps and extensive areas of fluviatile alluvium are used as further support for coastal sinking along the shore near Susuka Village (Hughes 1981, Manser 1985).

\section{Weather and Climate}

The mean annual rainfall at Taro, the Lauru provincial capital, on the extreme northwestern coast is greater than $3,500 \mathrm{~mm}$ with rain falling on more than 260 days per year. It is likely that higher rainfall levels would be recorded from inland and upland slopes, particularly higher slopes on windward-facing shores. More detailed weather data are available from Kieta, located on a northeast exposure that is similar to the study site. A climate diagram for Kieta (see Mueller-Dombois and Fosberg 1998) indicates a fairly uniform annual temperature and rainfall patterns. The climate of the Solomon Islands (including
Lauru Island) is generally hot $\left(22-29^{\circ} \mathrm{C}\right)$ and humid with only slight seasonality being recognized in wet and dry seasons (respectively November-April and May-October). Annual rainfall is $3,000-5,000 \mathrm{~mm}$ with variation based upon altitude and rain shadow effects of mountains and prevailing winds (Hansell and Wall 1976a).

No weather or climatic records have been identified for the research site, but daily temperature and weather records for the preliminary field research period of 30 May-29 June 1999 indicated daily temperatures ranging from 24 to $29^{\circ} \mathrm{C}$ in humid conditions, with 14 out of 30 days having at least some rain and 2 days of torrential rain.

\section{Flora}

Although the Solomon Islands does not have a floristic treatment, a number of important works have been compiled that address certain floristic resources (Guppy 1906, Kajewski 1930, 1946, Fosberg 1940, White 1946, Walker 1948, Good 1966, Whitmore 1966, 1969, Thorne 1969, Stone 1970, 1981, Foreman 1971, Hansell and Wall 1976b, Henderson and Hancock 1988, Dowe 1989, Olsen and Turnbull 1993, Anonymous 1995). A recent floristic inventory of tropical countries (Campbell and Hammond 1989) did not even mention the Solomon Islands, presumably because of a lack of current research activities. The flora of the Solomon Islands (including Lauru) consists of five principal elements (Whitmore 1966): (1) widespread strand species with distributions in the tropical western Pacific and eastern Indian Ocean areas; (2) widespread lowland species distributed throughout Malesia and sometimes continental Southeast Asia; (3) Malesian species existing only on the east side of Wallace's line; (4) Melanesian species that are found only in New Guinea, Solomon Islands, and Vanuatu/Fiji that are often endemic to one or a few island upland areas; (5) Pacific island endemic species with limited distributions or distributions only in the Solomon Islands and north (Micronesian) or east (Polynesian) of the Solomon Islands. All of the Solomon Islands are forested with the exception of 
parts of the north coast of Guadalcanal that have persistent natural (Pendleton 1949) or anthropogenic grasslands. Human activities (plant selection, protection, propagation; burning; selected extraction; etc.) have affected virtually all of the forests to a greater or lesser extent, with some areas presumably entirely the result of thousands of years of human manipulations. Relative levels of secondary forest succession are probably maintained through repeated cycles of cultivation and fallow periods, which otherwise would result in regeneration of long-term canopy forests. In some cases (such as on Kolobaqara Island) human activities have been partially discontinued and the forest successional cycle of cultivated areas has since returned them to long-term forests. In this way, human activities have contributed to diversification and expansion of certain niches that before human occupation may have occurred only rarely or in widely dispersed areas. At the same time, these traditional activities have not caused extensive long-term damage to the forest ecosystems. In contrast, recent high-impact activities, such as logging with heavy equipment, have resulted in extensive long-term destruction of forests through compaction of soil, heavy erosion (and resulting silting of estuaries/reefs), and overharvesting of selected species with reforestation by introduced species of Eucalyptus.

The flora of the Solomon Islands is estimated to consist of at least 5,000 species, of which about 2,500 probably occur on Lauru. The number of species is expected to exceed that of many other Pacific islands (Smith 1979, Wagner et al. 1990) but to be less than that of the largest Pacific island, New Guinea (Womersley 1978). Herbarium collections at the national herbarium in Honiara are scanty from Lauru but are growing rapidly because of recent concerted efforts to collect in the Western and Choiseul Provinces. Of the expected 2,500 species, at least 1,500 are represented in the herbarium, including over 500 species from the study site.

An intitial botanical survey of the study site was completed in June 1999. W.C.M. trained a group of 15 volunteers in plant collection and voucher specimen processing methods. The group then met with members of the Ririo Cucuen Cultural Project and used a free-listing method to identify a large number of named plants known to the group. The volunteers then proceeded to collect voucher specimens of these plants for later identification. Appendix 1 lists the plants that have been collected from research site 1 , Susuka watershed. The same free-listing method was used to elicit categories of vegetation recognized by members of the Ririo and Babatana communities. The volunteers worked under the supervision of the authors and Michael Wysong, using randomly located taxonomic transects of examples of each lowland vegetation type recognized by the Ririo to generate further collections of plant specimens. Initial floral collections focused upon documentation of ethnobotanically important plants in the immediate proximity of the sea level/strand villages of the Ririo tribe. Higher-altitude villages and vegetation zones have not yet been explored. Plants collected were examined in Honiara and used to establish a new herbarium based in the village of Susuka. This herbarium is currently housed in the Susuka Primary School and is being used in primary education of children as well as research activities of the local community. Development of this herbarium as a community training center was consistent with the goals of SIBI and prior recommendations for inclusion of local communities into the research process (Grano 1993).

\section{Fauna}

At least 163 species of land birds breed in the Solomon Islands including 72 endemic species. In addition, 62 species are represented by unique subspecies in the Solomons (Diamond and Mayr 1976). Many of these species are found on Lauru. "There is no other place in the world, not even the Galapagos Islands, where speciation and population variation between islands is so marked as in the Solomon Islands" (Diamond 1976). Researchers from the University of Washington have initiated studies on bird diversity on Lauru and the data are not yet available. Mammals, including endemic bats, rats, and opossums, 
are found on Lauru. Four of these mammals (ring-tailed rat, Melomys bougainvillea; monkey-faced flying fox, Pteralopex anceps; Poncelot's giant rat, Solomys poceleti; and naked-tailed rat, Solomys salebrosis) are found only on Lauru (Flannery 1990, 1995). Bowen-Jones et al. (1995) explored a range of environments around Lauru focusing on distributions of flying foxes but also noting the presence of bird and reptile species that were encountered. Their report emphasized the importance of conserving forest resources for preservation of the fruit bat populations and concluded with a suggested conservation action plan for development of a conservation area on the side of Mount Maetabe around the area of Saralata Village. Saralata is currently uninhabited and lies on the northwest slope of Mount Maetabe at the edge of the study site proposed here.

Insects of the Solomon Islands have been little studied. Based upon the estimated numbers of Lepidoptera species in the Solomon Islands ( 2,290) (Tennent 1998) and the calculation system of Hammond (1992), Jeremy Holloway (1999, pers. comm.) estimated that the Solomon Islands has 14,511 described insect species and 46,015 total insect species. This calculation implies that less than one in three species of insects from the Solomon Islands have been described. It is reasonable to assume that a substantial share of the total fauna of the Solomon Islands is represented on Lauru because other life forms (plants, mammals, and birds) are well represented there.

The fauna of the study site has not been formally surveyed although the linguist Donald Laycock tentatively identified several bird species from Susuka (unpublished notes included in Appendix 2). Bowen-Jones et al. (1995) identified birds, reptiles, and mammals from Varisi, Sisiga, and Babatana Territories on the north, west, and south, respectively, of the study site (Appendix 2). They also collected local names for many of the species identified, but our local collaborators do not always agree with the vernacular names that Bowen-Jones et al. reported. We have added our records of Babatana and Ririo names from the study site to Appendix 2.

\section{Vegetation and Vegetation Profiles}

The vegetation of Lauru has never been completely surveyed, and vast tracts remain unseen by scientists. However, the Solomon Islands Ministry of Forestry, Environment, and Conservation has studied the forestry resources (Anonymous 1995). In 1995 the island was found to have $1,152.5 \mathrm{~km}^{2}$ of merchantable forest, of which $60 \mathrm{~km}^{2}$ have been logged (Anonymous 1995); $95 \mathrm{~km}^{2}$ or $2.9 \%$ of the total land area have been cleared (Hansell and Wall 1976b) for traditional gardens and other purposes. All vegetation types (see Table 1) are present on Lauru except for seasonally dry forests and grasslands.

Preliminary observations of the study site indicate the presence of all vegetation types found on Lauru except for forest on ancient limestone. However, it is likely that areas of ancient limestone karst will be identified in the upland areas of the northern slopes of Mount Maetabe at the southeastern corner of the study site. Customary terminology for vegetation zones in the study site is reported in Table 2. These vegetation zones represent culturally important resource areas rather than cohesive ecosystems. It is interesting to note the similarities between usage areas and vegetation zones in Table 1.

\section{Customary Human Activities}

The cultures of the western Solomon Islands (Western and Choiseul Provinces) are of mixed Austronesian (Melanesian) and nonAustronesian (Papuan) ancestry. The people of Lauru Island speak related Austronesian languages with persistent linguistic and social affinities with cultures on Bougainville in adjacent Papua New Guinea. Eight languages are spoken on Lauru: Avasö, Babatana, Ririo, Sisiqa, Tavula, Vaghua, Varesi, and Vasiqasiqa (Capell 1962, Tryon and Hackman 1983; Malcom Ross, 1999, pers. comm.). Native language speakers account for almost the entire population of Lauru, totaling less than 17,000 people. Of the Lauru languages, Babatana and Varesi are currently the more widely used languages because of a historical activity: translation of the Bible (Varesi by Catholics 
and Babatana by Protestants). Biblical texts have not been translated into the other languages, so speakers of those languages have learned either Babatana or Varesi to practice

TABLE 1

Vegetation Zones of the Solomon Islands (Modified from Whitmore [1966, 1969], Henderson and Hancock [1988], Mueller-Dombois and Fosberg [1998])

1. Coastal strand vegetation

2. Mangrove forests

3. Freshwater swamp forest and herbaceous wetland vegetation

4. Lowland rain forest on well-drained soils

5. Forest on ancient limestone

6. Seasonally dry forest and grassland (probably not present on Lauru)

7. Montane forest and scrub

8. Anthropogenically modified vegetation

8a. Freshwater swamp agriculture

8b. Arboriculture systems

8c. Dry land root crop agriculture the islandwide adopted religion, Christianity. The Babatana language, as used in words in the text, includes letters based upon the Methodist translation system that are not spoken as they might be in English. For example, $b$ is pronounced as " $m b$." Translation activities have been confined almost exclusively to production of the books of the Bible and hymns and other church-related works. Almost no written records exist of Babatana words for commonly observed objects (e.g., parts of a house or digging sticks), technologies (e.g., fishing strategies), or terminologies (e.g., landscape/ecosystem terms). The Ririo language has never been formally studied although Donald Laycock conducted a preliminary survey of glosses in 1978 that was compiled by Lincoln (1999). Using Lincoln's compilation, the Ririo Cucuen Cultural Project has prepared a preliminary RirioBabatana-English dictionary. This dictionary includes all of the plants, animals, and vegetation zones listed here as well as additional

TABLE 2

Culturally Recognized (Babatana and Ririo) Vegetation Zones in the Proposed Lauru PABITRA Site

\begin{tabular}{lll}
\hline \hline Ririo & Babatana & Natural Vegetation/Usage Zones \\
\hline kol & kolo & Open sea \\
malav & malavo & Outer reef \\
ar kidavan & - & Area between inner and outer reef \\
quar' & - & Channel between inner and outer reef \\
bo' & bau & Shore and inner reefs \\
gargar soqom & - & Tidal beach \\
ve karkuin & gazu ni karakone & Coastal strand vegetation \\
- & lumi podolo & Mangrove forest \\
nob & po & Freshwater swamp forest (and agricultural sites) \\
vike & zike & Brooks or streams \\
vuv lean & - & Steep part of river such as a vertical waterfall that blocks \\
& kakako & the movement of fish \\
malko o & sakapa & Seasonally dry creek beds that only flow after heavy rains \\
sa kap & loka pota & Lowland rain forest \\
tat buan & - & Montane bogs/ponds characterized by stunted vegetation \\
siniqa & - & Forest/bush \\
& - & Montane forest \\
sup & & Mountain top (exposed rock/soil) \\
& komala sisipo & Anthropogenic Vegetation/Usage Zones \\
kuamal sisipa & po & Human settlements \\
nob & quana & Freshwater root crop agriculture areas \\
quan & baroe & Lowland rain forest arboriculture gardens \\
bab roe & kobe & Vegetable and root crop gardens \\
koeb & piara & Landslide areas \\
piar & & Former gardens (10-20 yr old) reverted to secondary forest \\
\hline & &
\end{tabular}


ethnobiological terminologies, and it is hoped that the dictionary can be published soon.

Before European contact and the introduction of Christianity (Methodism in 1905), the cultures of Lauru existed in isolated tribal groups in interior defendable upland villages. These villages were located on hilltops, ridge saddles, and other higher areas in the forest. In those situations, the people depended upon the forest resources for their primary sustenance but also maintained small forts and canoe sheds along rivers and next to protected lagoons for fishing and warfare purposes. Although it is not certain how commonly wars occurred, it is clear that the cultures of Lauru were constantly prepared for attacks (by living in defendable positions) and maintained weapons and war canoes (presumably for attacking enemies). Ancient hill forts consisted of a large compound surrounded by an outwardly bent living fence of useful trees and a single entrance that was physically blocked by the house inhabited by the tribe's young unmarried men, who served as the first line of defense. Within the compound, fruit and nut trees were grown for shade, nutrition, etc. Outside the village compound, but in similar raised areas, groves of trees were maintained as agroforestry plantations and gardens. Secondarily, swampy or dry areas were cultivated for sweet potatoes, yams, taro, bananas, etc.; these were undefendable positions and therefore risky places to work or live.

Babatana tribes formerly dominated the south-central portion of Lauru. Through recent marriages and movements of tribal members, they are now found throughout much of Lauru but particularly along the north-central coast. Almost all of the current Babatana and Ririo villages are located along the coastline or just inland near modern garden sites. Modern gardens are not necessarily located at the same sites as those of pre-European contact but in many cases are located on the adjacent slopes of hills with the useful tree groves that once served as village sites and harvest areas. In addition to shifting the sites of villages closer to the ocean, there have been substantial changes in diet and daily activities. Previously (presum- ably) the diet consisted of largely nuts, fruits, opossums, wild pigs, and other forest plants and animals, supplemented by root crops, fish, and other domesticated strand and swamp species. Currently, the diet consists of a mixture of domesticated root crops, fish, and imported foods such as rice, tinned fish, dry biscuits, etc.; these are supplemented by nuts and fruits of the forest and other forest animals and plants.

Currently, the human population level of Lauru is estimated to be greater than 16,000 persons or five per $\mathrm{km}^{2}$. The population is unevenly distributed, with greater populations in the northwest, south-central, and southern regions (Anonymous 1995). These populations are located primarily at coastal village sites established by missionary activities that began in the early 1900s. Before missionization, much of the population lived in higher-altitude defensible positions in the interior of the island. Some people still live in the upland regions and participate in subsistence farming practices only slightly modified from those of the distant past.

During initial visits to Lauru, some background ethnobotanical information was recorded from observations and interviews with villagers. Lauru islanders traditionally practiced a combination of hunting and gathering of wild foods (including Gnetum gnemon, Canarium salomonense, Pandanus sp., opossum, and wild pig), arboriculture (including Artocarpus altilis, Canarium indicum, Cocos nucifera, Barringtonia spp., Metroxylon salomonense, and Terminalia spp.), and shifting agriculture (including Alocasia macrorrbiza, Colocasia spp., Cordyline fruticosa, Dioscorea alata, Musa acuminata $\times$ balbisiana). In addition, other nonfood daily needs were satisfied by selecting materials from the forest and nearby marine environments (including Calamus spp. for rattan; Cocos nucifera, Hibiscus tiliaceus, and Pandanus spp. for fibers; Atuna racemosa for sealing caulk; Canaga odorata, Canarium salomonense, Eugenia spp., Rbizophora apiculata, Vitex trifoliata, and Zingiber zerumbet for medicine; and Agathis, Campnosperma brevipetiolata, Calophyllym kajewskii, Dillenia spp., Metroxylon salomonense, and Vitex cofassus for housing, canoes, containers, 
firewood, etc.). Currently ethnobotanical research projects are being conducted by various nongovernmental organizations as well as by the authors on the southern and northern central coasts of Lauru.

As mentioned earlier, very little of the forest area has been converted to human uses $(\sim 2.9 \%)$. This is particularly true in the most rural areas where populations are highly dispersed and forest regeneration rates probably exceed customary human conversion activities.

Previous ethnobotanical research in the Solomon Islands has been limited largely to passing reports of social scientists about plant usage (Codrington 1891, Wheeler 1914, 1926, Thomas 1931, Blackwood 1932, 1935, Oliver 1955, 1991, Brookfield and Hart 1971) and botanists about cultural activities (Henderson and Hancock 1988). Although those works are helpful, the archaeological and prehistorical studies of Guppy (1887), Barrau (1958), Yen (1973, 1974, 1976, 1991, 1994), Powell (1976), Maenu'u (1979, 1980), Wickler and Spriggs (1988), and Kirch (1989) are most pertinent to studies of ethnobotany on Lauru. No important ethnobotanical research appears to have been conducted previously in the area of Susuka. The current research will therefore be a unique addition to the knowledge of customary human activities on the north-central coast of Lauru. The research site is a sparsely populated area with probably less than 200 people, almost all of whom are living customary subsistence lifestyles. Currently, we are working to determine the types and levels of traditional knowledge that are still present in the community as a first step in conserving the knowledge (Plotkin 1995). Some of the areas of important knowledge that have been identified include arboriculture, canoe construction, fiber arts, fishing, housing, medicine, and weapons. The project is also seeking to develop positive economic opportunities for the Ririo culture that are sustainable and respectful of the culture. The Ririo Cucuen Cultural Project supports and controls studies of ethnobotanical uses of biodiversity in the study site, and the continued support by those involved in this project is important for the success of PABITRA on Lauru.

\section{Modern Human Activities}

In major centers on Lauru, such as Taro (Choiseul Bay) and Sasamuqa, electricity is widely available from community or individual petroleum generators. Few export commodities are available to pay for modern conveniences such as electricity except for the forest biodiversity itself in the form of logs. The forests of the Solomon Islands have very high-grade timber (Pleydell 1970) with competing traditions of local usage. Small-scale chainsaw mills have been established in several villages, and the Eagon Resources Development Company, Ltd. (Solomon Islands) is currently conducting commercial logging in the northern and southwestern parts of the island. Eagon's logging activities were estimated in 1992 (Anonymous 1995) to have exported 110 million Solomon Islands dollars (US\$22 million) worth of timber, mostly in the form of round logs. The Eagon company is currently the largest employer on Lauru and accounts for the bulk of the commercial economy. The current rate of logging is thought to exceed a sustainable level (Olsen and Turnbull 1993, Anonymous 1995).

Minimal electrification is currently in place in Susuka Village using petroleum generators, although more conveniences are desired by the villagers. Locally owned, smallscale chainsaw logging is taking place, and foreign commercial offers to $\log$ the study site have been tendered to village leaders. It seems that inevitably, unless better offers are made, the lowland areas of the study site will be logged. It is hoped that the activities of this research will delay or prevent that event through documentation of the value of the forest, education of villagers about the true value of their timber and other forest resources, and development of small-scale alternatives to commercial logging.

\section{Current Research Facilities in the Site}

The proposed research site has a number of elements of infrastructure that present it as a prime site for PABITRA research activities. The most important element is the people 
of the Ririo Cucuen Cultural Project and the surrounding Ririo and Babatana communities. The people are open and receptive to development of research facilities and the presence of foreign researchers. At the same time there is a conservative mood in the culture that shuns rapid development and destructive activities such as commercial logging. As mentioned earlier, a cadre of about 15 parataxonomists has already been trained in collection and preparation of biological samples. Village leaders have eagerly embraced the training that occurred in preliminary site visits in 1999 and have provided invitations for research collaborators to return for actual research activities.

The Ririo culture is in undisputed control of the land within the proposed study site. Although there are some internal disputes among landowners, these are unlikely to impact the proposed research in any substantial way. Ririo lands extend from the open ocean up to the slopes of Mount Maetabe and to the low-altitude rain forest of the Kolobaqara river. All vegetation types found in Lauru are thought to be represented in the relatively small area of Ririo lands. Currently almost all human activities are concentrated around the village of Susuka. This has resulted in conservation of higher upland areas and areas more distant from Susuka.

Several buildings have been made available for research activities in and around Susuka. These include two houses for visiting researchers (more are available if needed), two plant-drying stations (in cookhouses), and usage of the community meeting hall for group activities and indoor training sessions. Additional buildings have been identified at the eastern edge of the study site in the Masi lotu mangrove swamp and at the southern edge of the site on the Kolobaqara River. A herbarium has been established in the Susuka Primary School, which was remodeled in June 1999, and plans have been drawn up for building a larger school facility that would be able to house an expanded herbarium and other research units. Discussions are also under way for construction of a new field station on the slopes of Mount Maetabe at the southeastern corner of the site. In all, three field stations are either present or being developed/expanded that will allow researchers to work in any vegetation zone on the site within a few hours walk of the facility.

Solar power is currently available at two of the field station sites, and importation of more solar panels is planned for the new school building. A gasoline generator owned by the University of Hawai' $i$ is currently available for use in any of the field stations as a supplement to the solar panels. Plant collection presses and other equipment have been stored in Susuka and at the Masi lotu site. In addition, plant presses and other equipment belonging to the researchers are stored in Sasamuqa just outside the site.

Transportation to and from the field site is the greatest limitation to work in the Ririo area. To travel to the field site, researchers must fly from Honiara to Choiseul Bay (2-3 hr) and then travel by open canoe (3-6 hr) to Susuka or Sasamuqa. Alternatively, supply ships from Honiara (2-3+ days travel) make regular stops (every 2-4 weeks) at the villages of Susuka and Sasamuqa. Susuka Village has purchased an aluminum boat and outboard engine that can be used for travel between Susuka and Choiseul Bay. In addition, there are many privately owned wooden and aluminum canoes and motors that can be hired for travel around Lauru. Usually on these trips, fuel is the major expense.

Sasamuqa, as a center of activities on Lauru, receives more services, has a hospital and telephone station, and is more often frequented by boats from the south (Western Province.) A road has been planned that will pass from Sasamuqa north through the study site to Susuka. The eventual opening of this road will ease access to most of the study site and to the services at Sasamuqa but will also increase other human activities and facilitate the spread of invasive species to higher altitudes and isolated parts of the site. Opening of the road seems to be inevitable, so transect studies in the areas surveyed for the road should be conducted as soon as possible to provide baseline data for measuring the impacts of the road. 
TABLE 3

SIBI and PABITRA Research Objectives for the Proposed Lauru Biodiversity Transects, Solomon Islands

Preliminary site surveys

- Determination of site characteristics

- Determination of local interests and needs (language documentation, development of alternatives of logging, etc.)

Development of national research capacity

- Improvements of physical infrastructure (e.g., herbarium and other research facilities)

- Scientific capacity building (training of professional and paraprofessional biologists)

Development of site research capacity

- Improvements of physical infrastructure (expansion of the Susuka field station, building a Mount Maetabe field station, expansion of the Kolobaqara River field station, building a Sasamuqa field station)

- Scientific capacity building (training of biological collectors/long-term observers, training of conservation leaders, training of ethnobotanical collectors/long-term observers)

- Provision of survey equipment (canoes with 40-hp outboard engines at Susuka and Sasamuqa), plant collection and monitoring equipment, animal/insect collection and monitoring equipment, weather-monitoring equipment (at Susuka, Mount Maetabe, and Sasamuqa)

Primary site studies

- Flora and fauna (collection of plant inventory by vegetation zone; vertical transect studies of vegetation and species altitudinal distributions; ethnobotanical studies of distributions and uses of species; ecological analysis of species, including rarity, ecological associations, etc.; ecological human impact analysis of each vegetation zone and major subzones)

- Ecosystem analyses (including soils, nutrient dynamics, and hydrology)

- Climate (measurement of short-term climate and weather patterns, establishment of long-term monitoring stations/sites staffed with local research participants)

Presentation and publication of results

- Reports submitted for use by local villagers and resource managers

- Handbook of basic climate, edaphic, biotic, and technical information about the sites

- Reports submitted to governmental and participating research units

- Symposium meeting presentations

- Scientific publications (biogeographical, ethnobotanical, etc.)

- Synthetic publications using data from this and other PABITRA sites to summarize patterns for horizontal transects across the Pacific

RECOMMENDATIONS FOR PABITRA RESEARCH IN THE SOLOMON ISLANDS

Considering methodologies outlined in the PABITRA Manual for Interactive Ecology and Management (http://www.botany.hawaii .edu/pabitra), Table 3 presents an outline of proposed PABITRA research activities in the Solomon Islands that is consistent with the mission and principles of SIBI. These research activities must include participation not only from multidisciplinary research teams but also from multiple segments of the Solomon Islands government and local villagers. Partners must include Solomon Islands government ministries and departments, Solomon Islands research institutions and nongovernmental organizations, external research institutions, and customary landholders/local villagers. These collaborative arrangements will help ensure that the PABITRA biodiversity research and its applications benefit all participants and stakeholders.

\section{Literature Cited}

Anonymous. 1995. Solomon Islands national forest resources inventory: The forests of the Solomon Islands. Vol. 4. Choiseul Province. Ministry of Forestry, Environment and Conservation, Solomon Islands Government, Honiara.

Barrau, J. 1958. A reconnaissance survey in the field of economic botany in western Melanesia. South Pacific Commission, Noumea, New Caledonia. 
Birch, J. 1989. Notes on the geology and topography of the Solomon Islands. Pages 49-53 in J. L. Dowe, ed. Palms of the Solomon Islands. The Palm and Cycad Societies of Australia, A. Webb and Sons, Brisbane, Australia.

Blackwood, B. 1932. Folk-stories from the Northern Solomons. Folk-lore 43:6196.

. 1935. Both sides of Buka Passage. Clarendon Press, Oxford, U.K.

Bowen-Jones, E., D. Abrutat, W. Markham, and S. Bowe. 1995. Report of the Bristol University, Choiseul 1995, survey of fruit bats on Choiseul, Solomon Islands. University of Bristol, U.K.

Brookfield, H. C., and D. Hart. 1971. Melanesia: A geographical interpretation of an island world. Methuen, London.

Campbell, D. G., and H. D. Hammond, eds. 1989. Floristic inventory of tropical countries: The status of plant systematics, collections, and vegetation, plus recommendations for the future. The New York Botanical Garden, Bronx, New York.

Capell, A. 1962. A linguistic survey of the south-western Pacific. South Pacific Commission, Technical Paper 136. Noumea, New Caledonia.

Codrington, R. H. 1891. The Melanesians: Studies in their anthropology and folklore. Clarendon Press, Oxford, U.K.

Coleman, P. J. 1970. Geology of the Solomon and New Hebrides Islands, as part of the Melanesian re-entrant, South-west Pacific. Pac. Sci. 24:289-314.

Coleman, P. J., J. C. Grover, R. L. Stanton, and R. B. Thompson. 1965a. A first geological map of the British Solomon Islands. Report 28. Reprinted from J. C. Grover et al., British Solomon Islands Geological Record 2:1-13.

- 1965b. Stratigraphic and structural notes on the British Solomon Islands with reference to the first geological map, 1962. Report 29. Reprinted from J. C. Grover et al., British Solomon Islands Geological Record 2:17-33.

Diamond, J. M., and E. Mayr. 1976. Speciesarea relation for birds of the Solomon Ar- chipelago. Proc. Natl. Acad. Sci. U.S.A. 73:262-266.

Dowe, J. L., ed. 1989. Palms of the Solomon Islands. The Palm and Cycad Societies of Australia, A. Webb and Sons, Brisbane, Australia.

Flannery, T. F. 1990. Flying foxes in Melanesia: Populations at risk. Bats 7:5-7.

. 1995. Mammals of the South West Pacific and Moluccan Islands. Reed Books, Sydney.

Foreman, D. B. 1971. A checklist of the vascular plants of Bougainville, with descriptions of some common forest trees. Botany Bulletin No. 5. Division of Botany, Department of Forestry, Lae, Papua New Guinea.

Fosberg, F. R. 1940. Melanesian vascular plants. Lloydia (Cinci.) 3:109-124.

Good, R. 1966. Some phytogeographical relationships of the angiosperm flora of the British Solomon Islands Protectorate. Philos. Trans. R. Soc. Lond. B Biol. Sci. 255:603-608.

Grano, S., ed. 1993. Solomon Islands: National environmental management strategy. National Environment Management Strategy [SPREP], Apia.

Grover, J. C. 1958. The Solomon Islands: Geological exploration and research, 1953-1956. British Solomon Islands Geological Survey, Memoirs 2.

Guppy, H. B. 1887. The Solomon Islands and their natives. Swan Sonnenschein, Lowery and Co., London. 1906. Observations of a naturalist in the Pacific between 1896 and 1899 . London.

Hackman, B. D. 1973. The Solomon Islands fractured arc. Pages 179-191 in P. J. Coleman, ed. The western Pacific. University of Western Australia Press, Perth.

Hammond, P. M. 1992. Species inventory. Pages 17-39 in B. Groombridge, ed. Global biodiversity: Status of the Earth's living resources. Chapman and Hall, London.

Hansell, J. R. F., and J. R. D. Wall. 1976a. Land resources of the Solomon Islands. Vol. 1. Introduction and recommenda- 
tions. Land Resource Study 18. Land Resources Division, Ministry of Overseas Development, Surrey, England.

. 1976b. Land resources of the Solomon Islands. Vol. 6. Choiseul and the Shortland Islands. Land Resource Study 18. Land Resources Division, Ministry of Overseas Development, Surrey, England.

Henderson, C. P., and I. R. Hancock. 1988. A guide to the useful plants of the Solomon Islands. Research Department, Ministry of Agriculture and Lands, Solomon Islands Government, Honiara.

Hughes, G. W. 1979. Ririo: Choiseul geological map sheet $\mathrm{CH} 4,1: 50,000$. 1st ed. Geological Survey Division, Ministry of Natural Resources, Solomon Islands Government, Honiara.

. 1981. The geology of the Ririo area, Choiseul: An explanation of the 1:50,000 scale map sheet $\mathrm{CH} 4$. British Technical Cooperation, Western Solomons Mapping Project, Report 4. Geological Division, Ministry of Natural Resources, Solomon Islands Government, Honiara.

Kajewski, S. F. 1930. A plant collector's notes on the New Hebrides and Santa Cruz Islands. J. Arnold Arbor. Harv. Univ. 11:172-180.

- 1946. Plant collecting in the Solomon Islands. J. Arnold Arbor. Harv. Univ. 27:292-304.

Kirch, P. V. 1989. Second millennium B.C. arboriculture in Melanesia: Archaeological evidence from the Mussau Islands. Econ. Bot. 38 (3): 287-303.

Lincoln, P. 1999. Ririo-English word finder list based upon the work of Donald Laycock. Manuscript, Hamilton Library, Pacific Collection, University of Hawai'i at Mānoa, Honolulu.

Maenu'u, L. P. 1979. An indicative list of medicinal plants. Manuscript, Solomon Islands National Herbarium, Honiara.

- 1980. Solomon Islands traditional medicines. Vol. 1, Nos. 1 and 2 in A journal of Solomon Islands studies. University of the South Pacific, Solomon Islands Centre, Honiara, Solomon Islands.
Manser, W. 1985. Annotated bibliography and index: Geology and geophysics of the Solomon Islands to 1982. Geology Division, Ministry of Natural Resources, Bulletin No. 15, Honiara, Solomon Islands.

McCoy, M. 1980. Reptiles of the Solomon Islands. Wau Ecology Institute, Lae, Papua New Guinea.

Mueller-Dombois, D. 1998. Plant biodiversity in tropical ecosystems across the AsiaPacific region. Pages 105-113 in C. H. Chou and K. T. Shao, eds. Frontiers in biology: The challenges of biodiversity, biotechnology and sustainable agriculture. Academia Sinica, Taipei.

Mueller-Dombois, D., and C. C. Daehler. 2005. The PABITRA project: Island landscapes under global change. Pac. Sci. 59:133-139 (this issue).

Mueller-Dombois, D., and R. Fosberg. 1998. Vegetation of the tropical Pacific islands. Ecol. Stud. Anal. Synth. 132.

Oliver, D. L. 1955. A Solomon Island society: Kinship and leadership among the Siuai of Bougainville. Beacon Press, Boston, Massachusetts.

—. 1991. Black islanders: A personal perspective of Bougainville, 1937-1991. University of Hawai'i Press, Honolulu.

Olsen, M., and M. Turnbull. 1993. Solomon Islands national forest resources inventory. Assessment of the growth rates of logged and un-logged forests in the Solomon Islands: Review of literature. Australian International Development Assistance Bureau, Working Paper 17. Honiara, Solomon Islands.

Pendleton, R. C. 1949. The rain shadow effect on the plant formations of Guadalcanal. M.S. thesis, Weber State College, Ogden, Utah.

Pleydell, G. J. 1970. Timbers of the British Solomon Islands. Levers Pacific Timbers Limited, Kolombangara, Solomon Islands.

Plotkin, M. 1995. The importance of ethnobotany for tropical forest conservation. Pages 147-156 in R. Schultes and S. von Reis, eds. Ethnobotany: Evolution of a discipline. Dioscorides Press, Portland, Oregon. 
Powell, J. M. 1976. Pollen, plant communities and prehistory in the Solomon Islands. In C. R. Green and M. M. Cresswell, eds. Southeast Solomon Islands cultural history: A preliminary survey. R. Soc. N. Z. Bull. 11:75-105.

Pudsey-Dawson, P. A. 1965. Notes on geological reconnaissances on Choiseul, 1957. Reprinted from J. C. Grover et al., British Solomon Islands Geological Record 2:1415.

Smith, A. C. 1979. Flora Vitiensis nova: A new flora of Fiji. Vol. 1. Pacific Tropical Botanical Garden, Lāwa'i, Kaua'i, Hawai'i.

Stone, B. C. 1970. Notes on the systematy of Solomon Islands' plants and some of their New Guinea relatives. XI. Reinwardtia 8 (1): 3-11.

1981. Contributions to the flora of the Solomon Islands. Gard. Bull. (Singapore) 34 (2): 209-222.

Tennent, W. J. 1998. Biodiversity and biogeography of Solomon Islands butterflies. M.S. thesis, University of Kent at Canterbury, U.K.

Thorne, R. F. 1969. Floristic relationships between New Caledonia and the Solomon Islands. Philos. Trans. R. Soc. Lond. B Biol. Sci. 255:595-602.

Thomas, E. L. G. 1931. Customs and beliefs in Buka. Oceania 2 (2): 220-231.

Tryon, D. T., and B. D. Hackman. 1983. Solomon Islands languages: An internal classification. Pacific Linguistics C-72. Australian National University, Canberra.

Wagner, W. L., D. R. Herbst, and S. H. Sohmer. 1990. Manual of the flowering plants of Hawai'i. Vol. 1. University of Hawai'i Press/Bishop Museum Press, Honolulu.

Walker, F. S. 1948. The forests of the British Solomon Islands Protectorate. The Government of the British Solomon Islands Protectorate, London. (Reprinted, 1962.)

Wheeler, G. C. 1914. An account of the death rites and eschatology of the people of the Bougainville Strait. Arch. Religionwiss. 17:64-112.
1926. Mono-alu folk-lore. George Routhledge \& Sons, London.

White, C. T. 1946. Botanizing in the British Solomon Islands. Aust. J. Sci. 9:62-64.

Whitmore, T. C. 1966. Guide to the forests of the British Solomon Islands. Oxford University Press, London.

- 1969. The vegetation of the Solomon Islands. Philos. Trans. R. Soc. Lond. B Biol. Sci. 255:259-270.

Wickler, S., and M. Spriggs. 1988. Pleistocene human occupation of the Solomon Islands, Melanesia. Antiquity 62:703-706.

Womersley, J. S., ed. 1978. Handbook of the flora of Papua New Guinea. Vol. 1. Melbourne University Press, Melbourne, Australia.

Yan, C. Y., and L. W. Kroenke. 1993. A plate tectonic reconstruction of the Southwest Pacific, 0-100 Ma. Pages 697-709 in W. H. Berger, L. W. Kroenke, and L. A. Mayer, eds., Proceedings of the Ocean Drilling Program, Scientific Results. Vol. 130. College Station, Texas.

Yen, D. E. 1973. Ethnobotany from the voyages of Mendaña and Quiros in the Pacific. World Archaeol. 5:32-43.

- 1974. Arboriculture in the subsistence of Santa Cruz, Solomon Islands. Econ. Bot. 28:247-284.

- 1976. Agricultural systems and prehistory in the Solomon Islands. In C. R. Green and M. M. Cresswell, eds. Southeast Solomon Islands cultural history: A preliminary survey. R. Soc. N. Z. Bull. 11:61-74.

1991. Polynesian cultigens and cultivars: The question of origin. Pages 67-95 in P. A. Cox and S. A. Banack, eds. Plants, islands and Polynesians: An introduction to Polynesian Ethnobotany. Dioscorides Press, Portland, Oregon.

. 1994. Melanesian arboriculture: Historical perspectives with emphasis on the genus Canarium. Pages 36-44 in M. L. Stevens, R. M. Bourke, and B. R. Evans, eds. South Pacific indigenous nuts. Australian Centre for International Agricultural Research, Canberra. 
Appendix 1

Plant Species in the Vicinity of Susuka Village

\begin{tabular}{|c|c|c|}
\hline Taxa & Ririo Name & Babatana Name \\
\hline Acalypha wilkseiana & popor sek & paparusake vuvune \\
\hline Acalypha grandis & popor sak & paparusake, parusake \\
\hline Acanthus ilicifolius & ra'ara'apuevek & raka poreke \\
\hline Acriopsis cf. javanica & siakel & siakale sele \\
\hline Acrostichium sp. & ponoq & gama \\
\hline Acrostichium aureum & poet, mali nabo & pote \\
\hline Actinorbytis calapparia & beil bues, bo'ovara & belebose, bokovara \\
\hline Aglaia samoensis & & kidu \\
\hline Albizia saman & vev've miqur & vavae miga \\
\hline Allium fistulosum & anian & aniani \\
\hline Allium cepa var. aggregatum & silati & silati \\
\hline Alocasia sp. & lubis & lubisi \\
\hline Alocasia macrorrbiza & voruku & voruku \\
\hline Alocasia sp. & & kuruvera \\
\hline Alpinia stapfiana & bubuat & tutupu mesara \\
\hline Alpinia rechingeri & saqeta & saqeta \\
\hline Alpinia oceanica & kukulo & pipiro \\
\hline Alpinia purpurata & rurup & rurupa \\
\hline Alpinia sp. & & zaizai \\
\hline Alpinia sp. & tual piar & talapira \\
\hline Alpinia sp. & rurup mes & rurupa mesara \\
\hline Alpinia rechingeri & saqeta & saqeta \\
\hline Alstonia scholaris & bo'o & bua \\
\hline Alstonia sp. & kukuir & kukuri \\
\hline Alstonia sp. & qol zo' & qalu veko \\
\hline Alstonia spectabilis & & makobele \\
\hline Alternanthera amoena & & julupu kiku \\
\hline Amaranthus sp. & zuk & \\
\hline Ananas cosmosus & kainopu & kanapu \\
\hline Annona muricata & bario ku luka & bario ni vaka \\
\hline Anodendron paniculatum & kanik paras & kaniki parasi \\
\hline Appendicula reflexa & siakel & siakale \\
\hline Appendicula pendula & siakel & siakale \\
\hline Appendicula sp. & siakel & siakale \\
\hline Arachis bypogaea & pinati & pinati \\
\hline Areca catechu & kos & kasu \\
\hline Areca guрруі & buan jav & kasu java \\
\hline Areca macrocalyx & kos pe & kasu paza \\
\hline Argusia argentea & subapepel & subapepele \\
\hline Artocarpus heterophyllus & bario ku luka & bario ni vaka \\
\hline Artocarpus altilis & bario vud & bario ni vudu \\
\hline Asplenium contiguum & & \\
\hline Asplenium sp. & sibuka moed & gadoe pöo \\
\hline Asplenium nidus & pöo & pöo \\
\hline Asplenium tenerum & & sirakokomole zoqa \\
\hline Atuna racemosa & lita & lita \\
\hline Averrboa carambola & pirak & piraka \\
\hline Bambusa blumeana & vot kor & loso karo \\
\hline Bambusa vulgaris & vot kor & loso vokani \\
\hline Barringtonia asiatica & pipic & pututu \\
\hline Barringtonia procera & zel & vele \\
\hline Barringtonia novae-byberniae & zel & vele \\
\hline Barringtonia sp. & kurkoron vel & karukarunu vele \\
\hline Barringtonia sp. & & vele bose \\
\hline Barringtonia niedenzuana & zel & vele \\
\hline Barringtonia edulis & zel & vele \\
\hline
\end{tabular}


Appendix 1 (continued)

\begin{tabular}{|c|c|c|}
\hline Taxa & Ririo Name & Babatana Name \\
\hline Barringtonia racemosa & zel ta qil & vele ta qili \\
\hline Barringtonia sp. & & vele sisira \\
\hline Bougainvillea glabra & vuvure ar poq & böböli varapaqo \\
\hline Bougainvillea spectabilis & vuvure ar poq & böböli varapaqo \\
\hline Brachiaria sp. & & töe peqo \\
\hline Brachiaria subquadripara & sisiu & sisiu \\
\hline Brassica chinensis & kavisi in cina & kavisi ni China \\
\hline Brassica oleracea var. bullata & kavisi in Enland & kavisi ni Enland \\
\hline Broussonetia papyfera & tuba & tuba \\
\hline Bruguiera sexangula & podol & podolo jimutu \\
\hline Bruguiera parviflora & podol & pitu, podolo \\
\hline Bruguiera gymnorrbiza & podol & podolo depa \\
\hline Bulbopbyllum gracillimom & siakel & siakale \\
\hline Bulbophyllum sp. & siakel & siakale \\
\hline Bulbophyllum moblianum & siakel & siakale tali koqomo \\
\hline Bulbophyllum piestobullon & sakel jimut & siakale jimutu \\
\hline Bulbophyllum grandiflorum & siakel & siakale \\
\hline Burckella obovata & noc & natu \\
\hline Cadetia hispida & siakel sel & siakale sele \\
\hline Caladium bicolor & man kuluka & zekata vaka \\
\hline Calamus bollrungii & suaq, piol & siku, pelo \\
\hline Calamus stipitatus & suaq, piol & siku, pelo \\
\hline Calamus vestitus & suaq, piol & siku, pelo \\
\hline Calopbyllum inopbyllum & buin & buni ni tikava \\
\hline Calophyllum sp. & qol ko‘o & qalu sirebe \\
\hline Calophyllum paludosum & pedpoas & pedeposa \\
\hline Calophyllum kajewskii & qol kok & buni qalu, qalu koko \\
\hline Calophyllum vitiense & qal & qalu buni \\
\hline Campnosperma brevipetiolata & toel & toele \\
\hline Cananga odorata & mudumud, mudmud & mudumudu \\
\hline Canarium sp. & ciniri & tinaru kubo \\
\hline Canarium indicum & ko'o & kaku \\
\hline Canarium salomonense & saq & saqa \\
\hline Canarium sp. & noqot & noqoto \\
\hline Canarium asperum & saq sibut & saqa ta sibutu \\
\hline Canna sp. & kaboka & kalakabuka \\
\hline Canna indica & vuvure sot & böböli sotu \\
\hline Capsicum frutescens & lob & sili \\
\hline Capsicum annuum var. grossum & pepa & pepa \\
\hline Carallia brachiata & saqam & saqama \\
\hline Carica papaya & manep & manepo \\
\hline Caryota rumphiana & kuarak & piku \\
\hline Cassia alata & bakua & bakua \\
\hline Casuarina equisetifolia & zor & zaru \\
\hline Casuarina sp. & zaru & zaru \\
\hline Ceiba pentandra & vee kunel & gazu böti luqa \\
\hline Celtis philippensis & siatu'uk, cucuanrika & sikatuku, sinarika \\
\hline Centella asiatica & ka'alua', pula ta kur & kaloka, basa ta kuru \\
\hline Centotheca lappacea & siukas & siukasi \\
\hline Centrosema sp. & & sisiu buluma kau \\
\hline Cerbera manghas & $\log 0$ & kari \\
\hline Ceriops tagal & demdem & damedame \\
\hline Chamaesyce prostrata & & sisiu kanai, sisiu varamana \\
\hline Chrysopogon aciculatus & sisiu varapaqo & sisiu varapaqo \\
\hline Citrus maxima & pomol & pomolo \\
\hline Citrus grandis & purut la'avoe & purutu lata \\
\hline Citrus aurantifolia & laeni & laeni \\
\hline
\end{tabular}


Appendix 1 (continued)

\begin{tabular}{|c|c|c|}
\hline Taxa & Ririo Name & Babatana Name \\
\hline Citrus limon & purut don & purutu vasiki \\
\hline Citrus sinensis & orij & oruji \\
\hline Citrus reticulata & madarini & madarini, majarini \\
\hline Claoxylon tumidum & cinima & tinima \\
\hline Clerodendranthus staminens & kalkua & kalakua \\
\hline Clerodendrum sp. & & vapela gaveve jimutu \\
\hline Clerodendrum buchananii & & kotaru leke \\
\hline Cocos nucifera & kuda & kuda \\
\hline Codiaeum variegatum & lupa & jajala kobaburi \\
\hline Coix lachryma-jobii & popod dou, qaran vud & popoda vasiki, qaruni \\
\hline Coleus saulellarioides & kalakua & kalakua \\
\hline Colocasia esculenta & man luim & zekata lumi \\
\hline Colona velutina & & modo, sako \\
\hline Cominsia gigantea & bör & zizinu mesara, rurupa vuvuni \\
\hline Cordyline fruticosa & jilupar, vulo & jilupara, zilupara \\
\hline Costus speciosus & zolzol, joljol & kalakabuka zolzol \\
\hline Cucumis lanatus & meleni & meleni \\
\hline Cucumis sativus & kiukaba & kiukaba \\
\hline Cucumis melo & meleni & meleni \\
\hline Cucurbita pepo & dur & duru \\
\hline Curcuma longa & puat & pota \\
\hline Cyathea sp. & qur & quru \\
\hline Cyathea vittata & zuk & zuku \\
\hline Cyathea sp. & bonok & lalapu \\
\hline Cyathea sp. & pudaqil & pudaqili \\
\hline Cycas rumphii & roro & roro \\
\hline Cymbopogon citrullis cf. coloratus & pala nuis & basa sivata \\
\hline Cyperus javanicus & & vulu jimutu \\
\hline Cyperus rotundus & & sisiu bakoso \\
\hline Cyrtosperma chamissonis & kekek & kakake \\
\hline Cyrtosperma johnstonii & miduk & miduku \\
\hline Datura candida & vuvure biol & böböli belo \\
\hline Davallia solida & & zuku kalikaliqava \\
\hline Delonix regia & loloqev & loqeve, Christmas tree \\
\hline Dendrobium moblianum & siakel & siakale ni bakoro \\
\hline Dendrobium salomenense & siakel nuab & siakale duru \\
\hline Dendrobium goldfichii & & siakale \\
\hline Dendrobium kietaense & siakel & siakale \\
\hline Dendrobium gnomus & konek & siakale \\
\hline Dendrocnide nervosa & kureqa zilamaren & kureqa zalerana \\
\hline Dendrocnide sp. & kureqa tiapar & kureqa depa \\
\hline Dendrocnide latifolia & & basa koreqa \\
\hline Dennstaedtia samoensis & vevemiqur & vavae miqa \\
\hline Derris sp. & vaku katur & vaku katuru \\
\hline Derris trifoliata & & vaku karakone \\
\hline Derris sp. & vavanen ve & vaku zoqa \\
\hline Derris sp. & leqleq & vaku karatokele \\
\hline Derris beterophylla & & vaku ni siniqa \\
\hline Derris sp. & tu'a & tabalio mesara \\
\hline Desmodium sp. & lalvar ta bek & lavara ta vasi \\
\hline Desmodium umbellatum & jia jan & je jana \\
\hline Desmodium ormocarpoidec & momorok te bek & lavara ta vasi \\
\hline Desmodium gangeticum & momorok te bek & lavara ta vasi \\
\hline Dianella ensifolia & & böböli tutu, ganana piru, kela \\
\hline Dicranopteris linearis & luqa & luqa \\
\hline Dillenia crenata & na'am & nakumu \\
\hline Dillenia ingens & na'am & nakumu \\
\hline
\end{tabular}


Appendix 1 (continued)

\begin{tabular}{|c|c|c|}
\hline Taxa & Ririo Name & Babatana Name \\
\hline Dillenia sp. & na'am & nakumu \\
\hline Dillenia salomonensis & na'am, sibir & nakumu, sibiri \\
\hline Dioscorea sp. & & noba vuru mokoso \\
\hline Dioscorea sp. & susui & susui \\
\hline Dioscorea esculenta & zoad, zuad & pana \\
\hline Dioscorea sp. & & noba kölopirir \\
\hline Dioscorea pentaphylla & ziqam & noba \\
\hline Dioscorea nummularia & ziqam & noba \\
\hline Dioscorea bulbifera & kalak & kalaka \\
\hline Dioscorea alata & ziqam, vuru mo'os & noba \\
\hline Diospyros hebecarpa & papaza piloto & papaza piloto \\
\hline Diospyros sp. & & püzapüza piloto \\
\hline Diplazium esculenta & muqa & muqa \\
\hline Diplazium proliferum & mel & zuku mali \\
\hline Dolichandrone spathacea & tui & tui \\
\hline Donax canniformis & nina & nine \\
\hline Elaeocarpus sphaericus & & kunu \\
\hline Eleusine indica & sisiu & sisiu bakoso \\
\hline Endospermum medullosum & ve poat & gazu pota \\
\hline Enhalus acoroides & sisluka & siluka püu \\
\hline Eрірremпит ріппаtum & poet & surubi \\
\hline Epipremnum dablii & poet & surubi \\
\hline Epipremnum amplissimum & poet & surubi \\
\hline Eragrostis japonica & & sisiu kukupa \\
\hline Eragrostis pilosa & & sisiu 1 \\
\hline Erythrina variegata var. orientalis & bir'bir & biribiri \\
\hline Etlingera sp. & rurup & rurupa vuvune \\
\hline Euodia bortensis & pula & basa pitalata, basa vule \\
\hline Euodia anisodora & pula & basa vasiki \\
\hline Euodia sp. & cinirkubo & tinirikubo depa \\
\hline Euodia elleryana & nulit sel & nuliti sele, qalo maka \\
\hline Excoecaria agallocha & pipilomatanan & pipilomatana \\
\hline Fagraea gracilipes & buburet & burate \\
\hline Fagraea racemosa & pusak & pusaka \\
\hline Ficus variegata & ro'os, luc & rokoso, lutu, jimutu \\
\hline Ficus sp. & pilabük & pilabaku \\
\hline Ficus chrysochaete & qula & qula siridema \\
\hline Ficus wassa & ka'ano don & kanava vasiki \\
\hline Ficus benjamina & ro'os & rokoso \\
\hline Ficus septica & mamal & mamala \\
\hline Ficus drupacea & ro'os & rokoso \\
\hline Ficus virgata & ro'os vovoq & sisiru pitalata \\
\hline Ficus tinctoria & sisiur & sisiru vasiki \\
\hline Ficus longibracteata & pilapilabük & pilapilabaku \\
\hline Ficus tinctoria & ro'os sisiru & rokoso sisiru \\
\hline Ficus sp. & kovolasa' at & kovaroka \\
\hline Ficus macrothyrsa & kua & kua \\
\hline Ficus salomonensis & boilel & bolele \\
\hline Ficus septica & & kanava depa \\
\hline Ficus copiosa & ka'ano la'avoe & kanava pitalata \\
\hline Ficus copiosa & & kanava vasiki \\
\hline Finschia waterbousiana & ka'anuekel & kanokele \\
\hline Finschia chloroxantha & $\mathrm{ka}^{\prime}$ anuekel & kanokele \\
\hline Flacordia rukam & & beri \\
\hline Flagellaria gigantea & popod, zar & popoda/zara \\
\hline Freycinetia sp. & matmeaq & matameqa \\
\hline Freycinetia sp. & mireqet & sasake \\
\hline
\end{tabular}


Appendix 1 (continued)

\begin{tabular}{|c|c|c|}
\hline Taxa & Ririo Name & Babatana Name \\
\hline Freycinetia sp. & riuk & riku \\
\hline Gardenia sp. & & böböli vaka pilapila \\
\hline Gmelina moluccana & qolzo'o & qalu veko \\
\hline Gnetum gnemon & keo'os & kekoso, leko \\
\hline Grammatophyllum scriptum & siakel & siakale \\
\hline Guettardia speciosa & ke ked vuar & kade vuara \\
\hline Guillainia purpurata & kolot & koloto \\
\hline Guillainia sp. & puiqar & kuiqara \\
\hline Guillainia sp. & & kuqara, koeqara \\
\hline Gulubia bombronii & marot & marato \\
\hline Halophila ovalis & siluka zapzap ta teq & siluka zapazapa ta vunu \\
\hline Heliconia solomonensis & suat & suata \\
\hline Heliconia indica & suat & suata tutu \\
\hline Heliconia lanata & suat & suata ka'u \\
\hline Helminthostachys zeylandica & deder pia (spel) & dedere \\
\hline Heterospathe minor & vuk & vuku \\
\hline Hibiscus rosa-sinensis & vuvure & böböli \\
\hline Hibiscus manibot & ras & rasa \\
\hline Hibiscus tiliaceus & vor & varu \\
\hline Homalium tatambense & sa & sa \\
\hline Homalomena cordata & pitu & pitu \\
\hline Hornstedtia scottiana & ruepeq & qio sele, qio mesara \\
\hline Hornstedtia lycostoma & ruepeq & ropeqe \\
\hline Horsfieldia spicata & vovorot & vovoroto (pito, sele) \\
\hline Hoya dodocatheiflora & kasior & kasioro, vika voka buili \\
\hline Hoya cominsii & potpot & potopoto \\
\hline Hoya guppyi & & nokoso pilapila \\
\hline Hydnophytum sp. & pijul & pujulu \\
\hline Hydnophytum longistylum & nener & nanari \\
\hline Inocarpus fagifer & piqe & qiqiti, lanava \\
\hline Intsia bijuga & kivil & kivili \\
\hline Ipomoea batatas & sisu & sisu \\
\hline$\stackrel{I}{\text { Ipomoea aquatica }}$ & sisu lum & sisu lumi \\
\hline Ipomoea pes-caprae & posovan & puso vanana \\
\hline$\stackrel{I}{\text { Ipomoea } \mathrm{sp} .}$ & pipia kuse & pipia kuse \\
\hline Ischaemum muticum & & sisiu paraka \\
\hline Ixora coccinea & vuvure lut & böböli lotu \\
\hline fatropha sp. & vuvure & böböli/my love \\
\hline Kleinhovia hospita & vilek & vilaki \\
\hline Leea indica & kikib puda & kikibi puda \\
\hline Leucosyke salomonensis & soos & soso, gazu ni sakapa \\
\hline Licuaka lauterbachii & laker & lakiri ${ }^{\circ}$ \\
\hline Lumnitzera littorea & & kakarunu \\
\hline Lycopersicon lycopersicum & tomato & tomato - \\
\hline Lycopodium phlegmarioides & vurune basan & vurene basana \\
\hline Lygodium sp. & lei - & lae - \\
\hline Lygodium palmatum & & lae \\
\hline Lygodium versteeghii & lei & lae \\
\hline Lygodium microphyllum & lei & lae \\
\hline Lygodium circinnatum & lei & lae \\
\hline Lygodium dimorphum & lei & lae \\
\hline Lygodium trifurcatum & lei & lae \\
\hline Macaranga tanarius & soesoe & soesoe \\
\hline Macaranga fimbriata & rumes & rumese \\
\hline Macaranga gigantea & tob & susukutu \\
\hline Macaranga sp. & hoq & koqo \\
\hline Macaranga sp. & kubevanan & kubevanana \\
\hline
\end{tabular}


Appendix 1 (continued)

\begin{tabular}{|c|c|c|}
\hline Taxa & Ririo Name & Babatana Name \\
\hline Mangifera salomonensis & miaq vud & kimaka ni vudu \\
\hline Mangifera mucronulata & miaq vud & kimaka ni vudu \\
\hline Mangifera minor & miaq vud & kimaka ni vudu \\
\hline Mangifera indica & miaq kuluka & kimaka ni vaka \\
\hline Manibot esculenta & toviok & tovioko \\
\hline Mariscus javanicus & lot puat & lato pota, vulu jimutu \\
\hline Melastoma affine & no'os vurip & nokoso kamata \\
\hline Melochia umbellata & kuadman & kodame \\
\hline Merremia bracteata & rurui & rurui \\
\hline Merremia pacifica & rurui & rurui \\
\hline Merremia peltata & rurui & rurui \\
\hline Metroxylon salomonense & katua, karmo & nive \\
\hline Microsorium sp. & pöo & pöo \\
\hline Mikania micrantha & no'os sa'at & nokoso roka, milo miniti \\
\hline Mikania cordata & sisiu gojol & sisiu qaqaqara \\
\hline Mimosa pudica & sisiu varapaqo & sisiu varapaqo \\
\hline Mimosa invisa & sisiu varapaqo & sisiu varapaqo \\
\hline Morinda citrifolia & kukuir, vatkuic & kukuri \\
\hline Mucuna elegans & & qalo qum \\
\hline Muntingia calabura & ve seri & gazu seri \\
\hline Murraya paniculata & vuvure nonopok kuse & nanabu kuse \\
\hline Musa maclayi & siku kal & siku kalo \\
\hline Musa acuminata $\times$ balbisiana & suaq & siku \\
\hline Musa peekeli & siku kal & siku kalo \\
\hline Musa erecta & siku kal & siku kalo \\
\hline Myristica fatua & piqet ta ka'as & papele rokoso, buni ta qili \\
\hline Myrmecodia salomonensis & pujul & pujulu \\
\hline Nastus productus & vot kor & loso pöu, loso voto \\
\hline Nastus obtusus & los, vot kor & loso voto, loso bose (bekoto) \\
\hline Nephrolepis birsutula & kubasbo'o & kubasaboko \\
\hline Nephrolepis exaltata & sira kukuemel & sira kokomele zoqa \\
\hline Nephrolepis biserrata & veve biol, niqich & vavaebelo, kobasaboko, sirakokomele zoqa \\
\hline Nicotiana tabacum & vir & viri \\
\hline Nypa fruticans & rabia & rabia \\
\hline Ocimum americanum & pula meaq saq & basa meqa saqa \\
\hline Ocimum basilicum & pula zabau, pula tiapar & basa zabana, basa marata \\
\hline Ocimum sanctum & pula don & basa vasiki vurenea, basa koreqa \\
\hline Ocimum sp. & pula ta pituel & basa ta pitikole \\
\hline Octomeles sumatrana & vurima & vurima \\
\hline Oryza sativa & rais & raesi \\
\hline Osmoxylon novo-guineenis & kuijkuij, qires & qirese, kujikuji, tabu katu \\
\hline Oxalis corniculata & sisiu jiaprans & sisiu kolova \\
\hline Pandanus tectorius var. variegata & bul & bulu, vulu \\
\hline Pandanus poronaliva & solnire & solonire \\
\hline Pandanus sp. & por bas & poro basa \\
\hline Pandanus sp. & pür & poro \\
\hline Pandanus tectorius & ganan & ganana \\
\hline Pandanus compressus & som & samu \\
\hline Pandanus sp. & lo & lo \\
\hline Pangium edule & ko'ocika & tinaru \\
\hline Parartocarpus venenosa & bubue & boboe \\
\hline Parinari glaberrima & lita & lita \\
\hline Paraserianthes falcataria & viv'ruin & viruni \\
\hline Parsonsia belicandra & tu'a & tabalio depa \\
\hline Paspalum conjugatum & sisiu ti pioq & sisiu tüe peqo \\
\hline Passiflora foetida & musmus & musumusu \\
\hline Pennisetum polystachyon & sibo & sisiu sibo \\
\hline
\end{tabular}


Appendix 1 (continued)

\begin{tabular}{|c|c|c|}
\hline Taxa & Ririo Name & Babatana Name \\
\hline Phaseolus vulgaris & & biniti \\
\hline Phaseolus sp. & no'os bulmako & nokoso bulu makou \\
\hline Phaseolus vulgaris & binit don & biniti vasiki \\
\hline Phragmites sp. & & döo \\
\hline Phragmites karka & nuis & sivata \\
\hline Phymatosorus scolopendria & $\overline{\text { püo }}$ & püo \\
\hline Physalis angulata & & purutu \\
\hline Piper wichmanii & kubis, luqusor & luqusuru \\
\hline Piper sp. & nonol sa qaqar & nanalu ni ta lumi \\
\hline Piper sp. & $\overline{\text { kura }}$ & $\overline{\text { musa }}$ \\
\hline Piper aduncum & nonol & nanalu \\
\hline Piper betle & $\overline{\text { sarap }}$ & sarapa \\
\hline Piper sp. & nonol sa'a pu'a & nanalu sa poka \\
\hline Planchonella firma & kukeq & $\overline{\mathrm{k}} \mathrm{k}$ eqe, kokeqe, karajujuku \\
\hline Planchonella thyrsoidea & zezel $^{1}$ & zazale \\
\hline Plenandra stabliana & kuijkuij & qirese, kujikuji \\
\hline Plumeria acuminata & sedi & sedi (gazu, bubuli) \\
\hline Plumeria obtusa & sedi & sedi (gazu, bubuli) \\
\hline Plumeria alba & sedi & sedi (gazu, bubuli) \\
\hline Plumeria rubra & sedi & sedi (gazu, bubuli) \\
\hline Polygala paniculata & sisiu vikisi & sisiu vikisi \\
\hline Polyscias filicifolia & mak, mak pula & makamaka jimutu \\
\hline Polyscias sp. & ma'ama'a, mak pula & makamaka \\
\hline Pometia pinnata & qiam, mod & qema, modo \\
\hline Portulacca grandiflora & vuvure dio & böböli koloko, kiku \\
\hline Pothos rumphii & riuqimut, riuk & kalikali qava jimutu, riku \\
\hline Premna corymbosa & garav & garovo \\
\hline Procris pedunculata & kekes bobs & kakasi bakoso \\
\hline Pseuderanthemum sp. & pipiala gever & vapela gavere \\
\hline Psidium guajava & kuav & kuava \\
\hline Psophocarpus tetragonolobus & binit dia par & biniti depadepa \\
\hline Pterocarpus indicus & gargar & varara \\
\hline Ptychosperma sp. & siskam & sikama \\
\hline Ptychosperma salomonense & keq & kaqe \\
\hline Ptychosperma latius & keq & kaqe \\
\hline Pyrrosia longifolia & lap gojgojol & zira gadoe siakale \\
\hline Quassia indica & & qiqiti takakasa \\
\hline Rhaphidophora korthalsii & puet & surubi \\
\hline Rhaphidophora stolleana & puet & surubi \\
\hline Rhaphidophora novo-guineense & puet & surubi \\
\hline Rhaphidophora australasica & puet & surubi \\
\hline Rhizophora apiculata & pitu & podolo zabana \\
\hline Rhizophora mucronata & pitu & pitu \\
\hline Rhizophora stylosa & pitu & pitu \\
\hline Rhopaloblaste elegans & jariu & jariu \\
\hline Rhus taitensis & puqas & poqasa \\
\hline Ricinus communis & susue & sosoe \\
\hline Saccharum officinarum & parak & paraka \\
\hline Saccharum edule & zivir & \\
\hline Saccharum spontaneum & vio & vio \\
\hline Saccharum robustum & parak & paraka \\
\hline Sararanga sinuosa & tib laman & saramani bose, lamana \\
\hline Sarcanthopsis nagarensis & siakel sel & siakale sele \\
\hline Saurauia sp. & kakalkirak & kalakiraka \\
\hline Scaevola taccada & kidua & kidua \\
\hline Schizomeria serrata & masal, kun & masala, kunu, gazu \\
\hline Schizostachyum variegatum & & pasuka kiroro \\
\hline
\end{tabular}


Appendix 1 (continued)

\begin{tabular}{|c|c|c|}
\hline Taxa & Ririo Name & Babatana Name \\
\hline Schizostachyum tessellatum & pasuka & pasuka \\
\hline Scindapsus altissimus & puet & surubi pajapaja \\
\hline Scindapsus cuscuaria & puet & surubi \\
\hline Scindapsus salomonensis & puet & surubi \\
\hline Scleria polycarpa & lot puat & lato pota, lato qili \\
\hline Securinega samoana & vurak pito & vuraka pito \\
\hline Securinega flexuosa & vurak & vuraka \\
\hline Selaginella rechingeri & pipi'ot & pepekoto \\
\hline Semecarpus anacardium & qitur & qituru \\
\hline Semecarpus forsterii & qitur & qituru \\
\hline Sida rbombifolia & dopolopu & dopolopu, posa korisi \\
\hline Sonneratia alba & garos & bulobulo \\
\hline Spathodea campanulata & veen Aprika & gazu ni Africa \\
\hline Spathoglottis plicata & & puae basana \\
\hline Spondias cyatherea & pirak & piraka \\
\hline Spondias dulcis & pirak & piraka \\
\hline Sporobolus indicus & sisiu & sisiu \\
\hline Stenochlaena palustris & gam & gama \\
\hline Synedrella nodiflora & & sisiu basa qole \\
\hline Syzygium sp. & kabikal & kapika pae \\
\hline Syzygium malaccensis & kabikal & kapika \\
\hline Syzygium sp. & vemear & kamekara \\
\hline Tacca leontopetaloides & siup siup kion & zapukeno \\
\hline Tectaria durvillei & & gadoe siakale \\
\hline Teijsmanniodendron bollrungii & quin & $\mathrm{ku}$ \\
\hline Terminalia solomonense & pavuam & pavoma \\
\hline Terminalia brassii & liaqar & leqara \\
\hline Terminalia kaernbachii & talik la'avoe & talike vuvune/talike lata \\
\hline Terminalia catappa & talike don & talike vasiki \\
\hline Terminalia calamansanai & sepqo - & sapeqava \\
\hline Thalassia sp. & siluka vot & siluka voto \\
\hline Thalassia sp. & mambuso & siluka ta qisulu \\
\hline Thalassia hemprichii & & siluka kukuli \\
\hline Theobroma cacao & kokoa & kokoa, kukua \\
\hline Thespesia populnea & & puqasa ni tikava \\
\hline Timonius timon & & togao \\
\hline Trichosanthes cucumerina & & binitit doledole \\
\hline Trichospermum psilocladum & voroq, mod & sako, modo \\
\hline Trichospermum sp. & lue & loe \\
\hline Trichospermum sp. & kuadam & kudame \\
\hline Uncaria appendiculata & popo'oc & papakutu, kara kutu \\
\hline Vernonia cinerea & & poreka \\
\hline Vigna marina & binit ta bo'o & biniti ta boko \\
\hline Vigna sesquipedalis & binit duel & biniti doledole, navanava \\
\hline Vitex negundo & palan kiu & pala na kiu \\
\hline Vitex cofassus & zedek & vadaka \\
\hline Vitex trifoliata & pulan liu & pala na kiu \\
\hline Wolstonia biflora & bubu & bubu, kalakua \\
\hline Xanthosoma lindenii & karuvera & karuvera \\
\hline Xanthosoma sp. & miduk & miduku \\
\hline Xanthosoma sagittifolium & qatokae & qatokae \\
\hline Xanthostemon sp. & rie & re, rie \\
\hline Zea mays & gazu va'a & \\
\hline Zephranthes grandiflora & & volao \\
\hline Zingiber officinale & puat lilib & pota \\
\hline
\end{tabular}

Note: Data collected by the authors and J. Mozena, J. Stevens, and M. Wysong in 1998-1999; vouchers on deposit in the Ririo Cucuen Herbarium and Honiara Herbarium, Solomon Islands. 
Appendix 2

Birds, Reptiles, and Mammals of Lauru Identified by D. Laycock (unpubl. data, 1979), McCoy (1980), Bowen-Jones et al. (1995), and Flannery (1995); Ririo and Babatana names determined without vouchers by the authors in 1999

\begin{tabular}{|c|c|c|c|c|}
\hline \multirow[b]{2}{*}{ Taxa: Scientific Name (Common) } & \multicolumn{4}{|c|}{ Lauru Languages } \\
\hline & Babatana & Ririo & Sisiga & Varisi \\
\hline \multicolumn{5}{|l|}{ Birds } \\
\hline Aceros plicatus (Blyth's hornbill) & & & tuno & koqomo \\
\hline Alcedo atthis (common kingfisher) & & & sege & - \\
\hline Alcedo azurea (azure kingfisher) & & & sege & - \\
\hline Anas superciliosa (Pacific black duck) & & & araga & araaraga \\
\hline Anous stolidus (common noddy) & & & kukui & pulepule \\
\hline Aplonis metallica (colonial starling) & & & ziu & - \\
\hline Aviceda subcristata (crested hawk) & & vikvik & - & pito \\
\hline Cacatua ducorpsi (Solomons cockatoo) & & $\mathrm{ka}^{6} \mathrm{as}$ & kakaza & kakassa \\
\hline Chalcopsitta cardinalis (cardinal lory) & & & visiri & viviri \\
\hline Charmosyna placentis (red-flanked lorikeet) & & & - & korokini \\
\hline Cbrycoccyx lucidus (shining cuckoo) & & & kroveo & - \\
\hline Collocalia esculenta (glossy swiftlet) & & & kelu & - \\
\hline Coracina lineata (yellow-eyed cuckoo shrike) & & & viu & - \\
\hline Coracina novaehollandiae (cuckoo shrike) & & & vese & - \\
\hline Coracina papuensis (White-bellied cuckoo shrike) & & & - & - \\
\hline Corvus woodfordi (Solomons crow) & & qoqo & - & - \\
\hline Dicaeum aeneum (Solomons flower pecker) & & & tetedeke & - \\
\hline Dracula rubricera (red-knobbed fruit pigeon) & & & gugutuni & kurukuru \\
\hline Ducula pacifica (Pacific imperial pigeon) & & & $\begin{array}{l}\text { kurukuru } \\
\text { karukei }\end{array}$ & - \\
\hline Ducula pistrinaria (grey fruit pigeon) & & & - & $\begin{array}{c}\text { kurukuru } \\
\text { kovele }\end{array}$ \\
\hline Eclectus roratus (eclectus parrot) & & & kera & $\begin{array}{l}\text { kira kobu/ } \\
\text { kira mesara }\end{array}$ \\
\hline Egretta alba (large egret) & & & - & - \\
\hline Egretta intermedia (intermediate egret) & & & - & so sele \\
\hline Egretta sacra (eastern reef heron) & & su & su & so pogo \\
\hline Eudynamis scolopacea (common koel) & & & - & qaqava \\
\hline Eurystomus orientalis (dollar bird) & & kikruabak & kikirobaka & -1 \\
\hline Fregata ariel (lesser frigate bird) & & & bellama & - \\
\hline Halcyon cbloris (collared kingfisher) & & sige & sege & $\begin{array}{l}\text { kinki nopoto } \\
\text { sele }\end{array}$ \\
\hline Halcyon sancta (sacred kingfisher) & & sige & sege & kinki nopoto \\
\hline Halcyon saurophaga (beach kingfisher) & & & keokeo & kiokio \\
\hline Haliaetus sanfordi (Sanford's eagle) & & & kamaga & - \\
\hline Haliastur indus (Brahminy kite) & & & pagege & $\begin{array}{l}\text { rapa rapa } \\
\text { sakanoko }\end{array}$ \\
\hline Hemiprocne mystacea (moustached tree swift) & & & kunuperu & - \\
\hline Megapodius freycinet (common scrub fowl) & nelo & kolpiur & nelo & keo \\
\hline Mino dumontii (orange-faced grackle) & & & kiregio & sirogo \\
\hline Nectarina jugularis (yellow-bellied sun bird) & & & pisu & - \\
\hline Nesasio solomonensis (fearful owl) & & & - & - \\
\hline Ninox jacquinoti (Solomons boobook) & & & kotukoturu & kururu \\
\hline Numenius madagascariensis (eastern curlew) & & & gelegele & qoqoqo \\
\hline Nycticorax caledonicus (nankeen night-heron) & & kuip & - & kopi sasaniga \\
\hline Pandion haliaetus (osprey) & & veve & ziruvage & malokumu \\
\hline Pluvialis dominica (eastern golden plover) & & & galigali & - \\
\hline Pluvialis squatarola (grey plover) & & & topetope & - \\
\hline Porphyrio porpyrio (purple swamphen) & & ko'duk & gute & quresa \\
\hline Ptilinopus viridus (red-breasted fruit dove) & & & koku & guzikuku \\
\hline Reinwardtoena crassirostris (crested cuckoo dove) & & & koko & dumoko \\
\hline Rhipidura cockerelli (lesser pied fantail) & & & - & - \\
\hline
\end{tabular}


Appendix 2 (continued)

\begin{tabular}{|c|c|c|c|c|}
\hline \multirow[b]{2}{*}{ Taxa: Scientific Name (Common) } & \multicolumn{4}{|c|}{ Lauru Languages } \\
\hline & Babatana & Ririo & Sisiga & Varisi \\
\hline Rhipidura leucophrys (willie wagtail) & & pit kuel & pitokole & - \\
\hline Rhipidura rufifrons (rufous fantail) & & pit kuel & pitokole & - \\
\hline Sterna bengalensis (lesser crested tern) & tom & & sisivai & palepale \\
\hline Sterna bergii (greater crested tern) & & & - & - \\
\hline Sula leucogaster (brown booby) & & & - & - \\
\hline Trichoglossus baematodus (rainbow lorikeet) & & & visiribeleke & qilevera \\
\hline Triga bypoleucos (common sandpiper) & bilikiki & & - & qiqiqi \\
\hline Zonerodius beliosylus (forest bittern) & & & - & - \\
\hline Zosterops metcalfei (yellow-throated white-eye) & & & geluku & - \\
\hline Zosterops ugiensis (grey-throated white-eye) & & & geluku & - \\
\hline \multicolumn{5}{|l|}{ Reptiles } \\
\hline Acrochordus granulatus (python) & & & dule & - \\
\hline Boiga irregularis (python) & & & dule kuba & - \\
\hline Candoia carinata (python) & & & kelesua & - \\
\hline Caretta caretta (loggerhead) & & & vunu & - \\
\hline Chelonia mydas (green turtle) & & & moga & - \\
\hline Corucia zebrata (skink) & & & pano & - \\
\hline Crocodylus porosus (crocodile) & & & poku & - \\
\hline Cyrtodactylus louisiadensis (gecko) & & kukan & kurukana & - \\
\hline Cyrtodactylus pelagicus (gecko) & & kukan & kurukana & - \\
\hline Dermochelys coriacea (leatherback turtle) & & & galo & - \\
\hline Emoia atrocostata (skink) & & & sudapa & - \\
\hline Emoia caeruleocauda (skink) & & & sudapa & - \\
\hline Emoia cyanogaster (skink) & & & sudapa & - \\
\hline Emoia cyanura (skink) & & & sudapa & - \\
\hline Emoia maculata (skink) & & & sudapa & - \\
\hline Emoia nigra (skink) & & & sudapa & - \\
\hline Eretmochelys imbricata (hawksbill turtle) & & & suri & - \\
\hline Gebydra oceanica (gecko) & & kukan & kurukana & - \\
\hline Gekko vittatus (gecko) & & kukan & kurukana & - \\
\hline Gonocephalus godeffroyi (agama lizard) & & & vego & - \\
\hline Hemidactylus frenatus (gecko) & & kukan & kurukana & - \\
\hline Lamprolepis smaragdina (skink) & & & kaputaka & - \\
\hline Laticauda colubrina (sea snake) & & rar & $\begin{array}{l}\text { dule } \\
\text { korotoboto }\end{array}$ & - \\
\hline Laticauda laticauda (sea snake) & & & dule jotanube & - \\
\hline Lepidodactylus lugubris (gecko) & & kukan & kurukana & - \\
\hline Lipinia noctua (skink) & & & sudapa & - \\
\hline Prasinobaema virens (skink) & & & sudapa & - \\
\hline Salomonelaps par (python) & & & dule pota & - \\
\hline Sphenomorphus concinnatus (skink) & & & sudapa & - \\
\hline Sphenomorphus cranei (skink) & & & sudapa & - \\
\hline Sphenomorphus tanneri (skink) & & & sudapa & - \\
\hline Varanus indicus (monitor lizard) & & & raka & - \\
\hline \multicolumn{5}{|l|}{ Mammals } \\
\hline \multicolumn{5}{|l|}{ Anthops ornatus (Solomons flower-faced bat) } \\
\hline \multicolumn{5}{|l|}{ Aselliscus tricuspidatus (trident horseshoe bat) } \\
\hline \multicolumn{5}{|l|}{ Chaerephon solomonis (Solomons mastiff bat) } \\
\hline \multicolumn{5}{|l|}{ Dobsonia inermis (Solomons bare-backed fruit bat) } \\
\hline \multicolumn{5}{|l|}{ Emballonura dianae (large-eared sheath tail bat) } \\
\hline \multicolumn{5}{|l|}{ Emballonura nigrescens (lesser sheath tail bat) } \\
\hline \multicolumn{5}{|l|}{ Emballonura raffrayana (Raffray's sheath tail bat) } \\
\hline \multicolumn{5}{|l|}{ Hipposideros calcaratus (spurred horseshoe bat) } \\
\hline \multicolumn{5}{|l|}{ Hipposideros cervinus (horseshoe bat) } \\
\hline Hipposideros diadema (diadem horseshoe bat) & & & & \\
\hline
\end{tabular}


Appendix 2 (continued)

\begin{tabular}{|c|c|c|c|c|}
\hline \multirow[b]{2}{*}{ Taxa: Scientific Name (Common) } & \multicolumn{4}{|c|}{ Lauru Languages } \\
\hline & Babatana & Ririo & Sisiga & Varisi \\
\hline \multicolumn{5}{|l|}{ Hipposideros dinops (giant horseshoe bat) } \\
\hline \multicolumn{5}{|l|}{ Macroglossus minimus (northern blossom bat) } \\
\hline \multicolumn{5}{|l|}{ Melonycteris woodfordi (Woodford's blossom bat) } \\
\hline \multicolumn{5}{|l|}{ Melomys bougainville } \\
\hline \multicolumn{5}{|l|}{ Miniopteris australis (little bent wing bat) } \\
\hline \multicolumn{5}{|c|}{ Miniopteris macrocneme (small Melanesian bent wing } \\
\hline \multicolumn{5}{|c|}{$\begin{array}{l}\text { Miniopteris propitristis (large Melanesian bent wing } \\
\text { bat) }\end{array}$} \\
\hline \multicolumn{5}{|l|}{ Miniopteris schreibersii (common bent wing bat) } \\
\hline \multicolumn{5}{|l|}{ Myotis adversus (large-footed mouse-eared bat) } \\
\hline \multicolumn{5}{|l|}{ Nyctimene bougainville (Solomons tube-nosed bat) } \\
\hline \multicolumn{5}{|l|}{ Nyctimene major (island tube-nosed bat) } \\
\hline \multicolumn{5}{|l|}{ Pipistrellus angulatus (New Guinea pipistrelle) } \\
\hline Pteralopex anceps (monkey-faced flying fox) & & - & kunjulu & - \\
\hline \multicolumn{5}{|l|}{ Pteropus admiralitatum (admiralty flying fox) } \\
\hline \multicolumn{5}{|l|}{ Pteropus mabaganus (Sanborn's flying fox) } \\
\hline \multicolumn{5}{|l|}{ Pteropus rayneri grandis (Solomons flying fox) } \\
\hline \multicolumn{5}{|l|}{ Roussettus amplexicaudatus (rousette bat) } \\
\hline \multicolumn{5}{|l|}{ Solomys ponceleti (Poncelot's giant rat) } \\
\hline Solomys salebrosis (naked-tailed rat) & & & & \\
\hline
\end{tabular}


